\title{
\begin{tabular}{l} 
MANN \\
SF \\
538 \\
.P55T \\
\hline
\end{tabular}

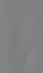
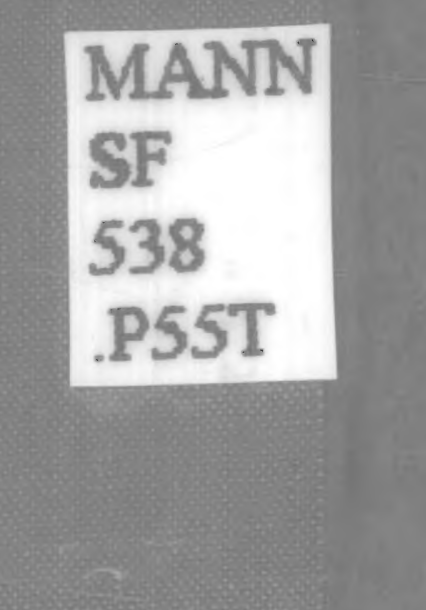

.

. 

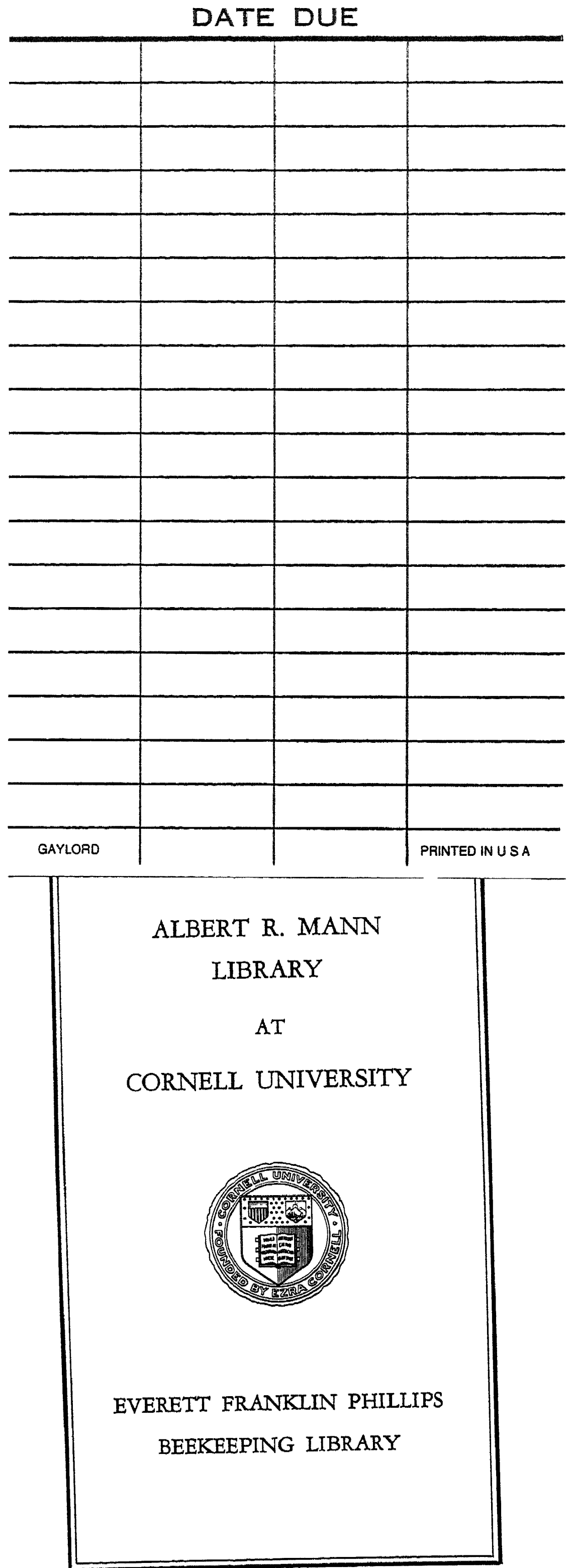
U. S. DEPARTMENT OF AGRICULTURE.

FARMERS' BULLETIN 442.

\section{THE TREATMENT OF BEE DISEASES.}

BY

E. F. PHILLIPS, PH. D.,

In Charge of Bee Culture, Bureau of Entomology.

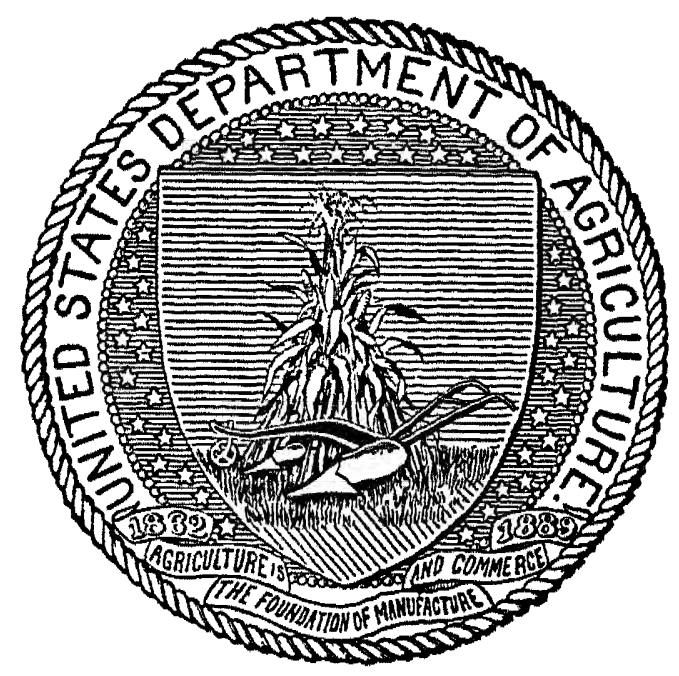

WASHINGTON:

GOVERNMENT PRINTING OFFICE. 


\section{LETTER OF TRANSMITTAL.}

\section{U. S. Departunent of Agriculture, \\ Bureau of Entontologr, \\ Washington, D. C., February $24,1911$.}

SIR: I hare the honor to transmit herewith a manuscript entitled "The Treatment of Bee Diseases," by E. F. Phillips, Ph. D., in charge of bee culture in this bureau. In the preparation of this paper, which is intended to supersede Circular 79, of this bureau, the aim has been to give briefly the information needed by the beekeeper who has disease in his apiary. No discussion of the cause or distribuition of these diseases has been included. I recommend the publication of this paper as a Farmers' Bulletin.

Respectfully,

L. O. Howard,

Entomologist and Chief of Bureau.

Hon. Janes Wilson,

Secretary of Agriculture. 


\section{CONTENTS.}

Introduction ...... Page.

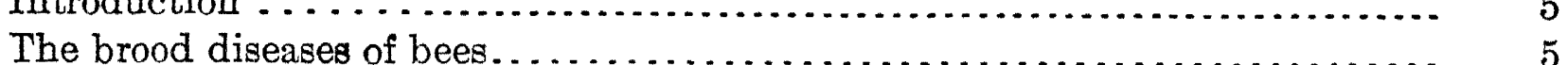

Nature of the diseases....................................... 7

Names of the diseases. . . . . . . . . . . . . . . . . . . . . .

Symptoms................................................. 8

American foul brood . . . . . . . . . . . . . .

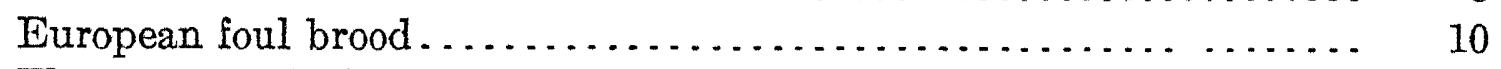

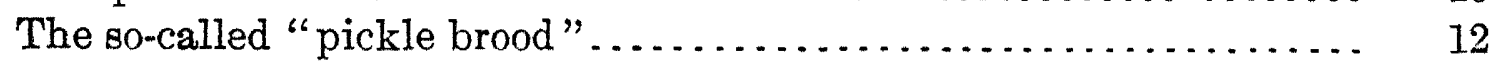

Brood dead of other causes. . . . . . . . . . . . . . . . . . . . . . . . 12

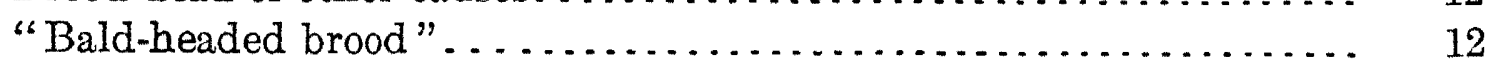

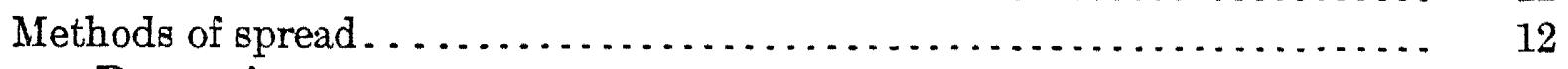

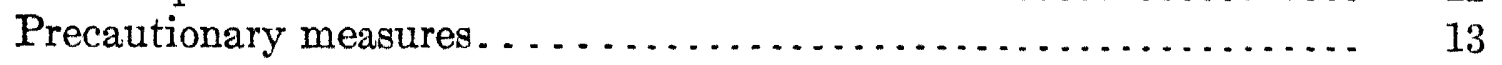

Treatment for both infectious diseases. . . . . . . . . . . . . . . . . . . 13

Shaking treatment..................................... 14

Time of treatment. . . . . . . . . . . . . . .

Preparation....................................... 14

Operation......................................... 14

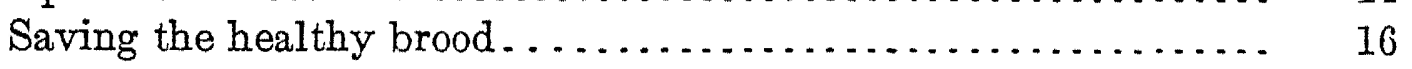

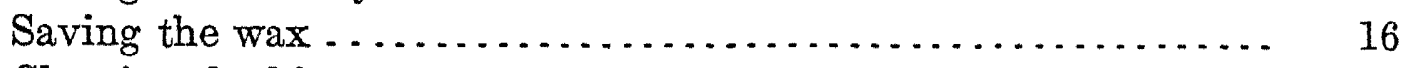

Cleaning the hive...................................... 16

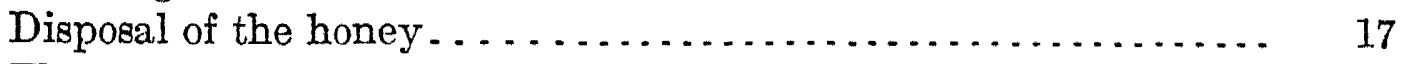

The second shake.................................... 17

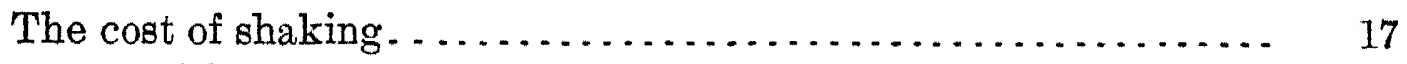

Treatment with bee escape............................... $\quad 17$

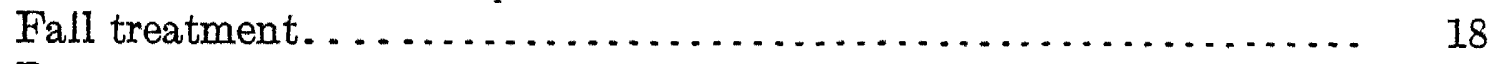

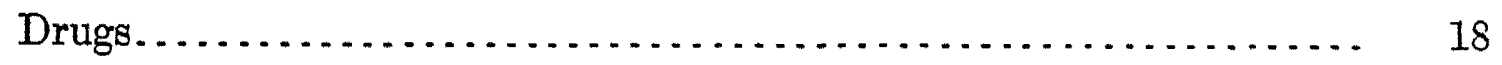

Treatment for European foul brood................................. 18

Introduction of Italian stock. . . . . . . . . . . . . . . . . . . . . . . . 19

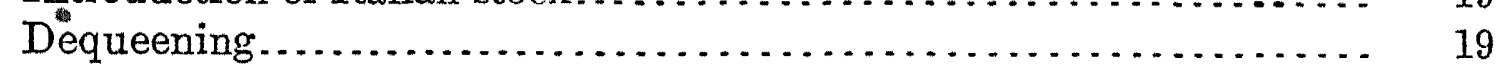

Inspection of apiaries............................................ 19

Examination of samples of diseased brood....................... 20

The diseases of adult bees..................................... 20

Dysentery................................................ 20

The so-called paralysis......................................... 21

Isle of Wight disease....................................... 21

Spring dwindling ............................................. 21

Publications of the Department of Agriculture on bee diseases ........... 22 


\section{ILLUSTRATIONS.}

FIG. 1. Work of the larger wax moth.

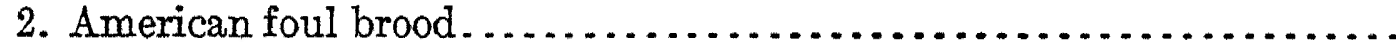

3. The ropiness of American foul brood ........................... 9

4. American foul-brood comb... ............................. 9

5. European foul brood ..... . .......................... 11

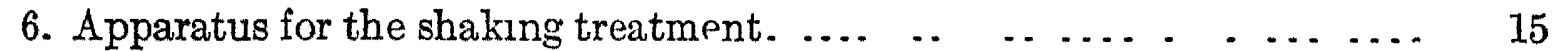

7. Gasoline torch....................................... 16

442 


\section{THE TREATMENT OF BEE DISEASES.}

\section{INTRODUCTION.}

The diseases which attack the honey bee may be divided into two classes, namely, those affecting the brood and those to which the adult bees are subject. The diseases of adult bees hare not been inrestigated sufficiently to make it possible at the present time to recommend methods for their treatment. In the present bulletin, therefore, only a brief statement concerning these diseases will be made, mainly for the purpose of indicating the present state of knowledge on these subjects. Concerning the diseases of the brood more is known, and this is particularly fortunate since they are far more destructive in American apiaries than are the diseases of the adult bees.

The causes of bee diseases will not be discussed here. For information on this phase of the subject the reader is referred to other publications of the Bureau of Entomology, which are listed at the end of this bulletin. The aim of this bulletin is to give information that can be used by the practical beekeeper in combating bee diseases.

\section{THE BROOD DISEASES OF BEES.}

The brood diseases of the honey bee are already widely distributed in the United States and seem to be spreading rather rapidly. The loss to the beekeepers of the country, orring to the actual death of colonies by disease, is estimated conservatively at $\$ 1,000,000$ annually. 'This does not include the loss of crops, resulting from the destruction of colonies, or the discouragement to the beekeeper which often causes him to give up the business. A considerable part of this loss is due to the indifference of the beekeepers to these diseases and a lack of knowledge concerning them.

It frequently happens that colonies in an apiary become infected before the owner realizes that disease is present. He may erroneously attribute the losses observed to sonse other cause. In this way the diseace gets a start which makes eradication difficult when once the cause of the loss has been discovered. In view of the widespread distribution of these diseases, it is most desirable that all beekeepers learn to distinguish the diseases when they appear and to know how to keep them under control.

It is often a matter of surprise to beekeepers to learn that bees are subject to disease. The most frequent source of confusion is the 
placing of the blame for loss of colonies on some cause other than disease. The poorer class of beekeepers attribute their losses simply to "bad luck," but even well-informed beekeepers err in this matter.

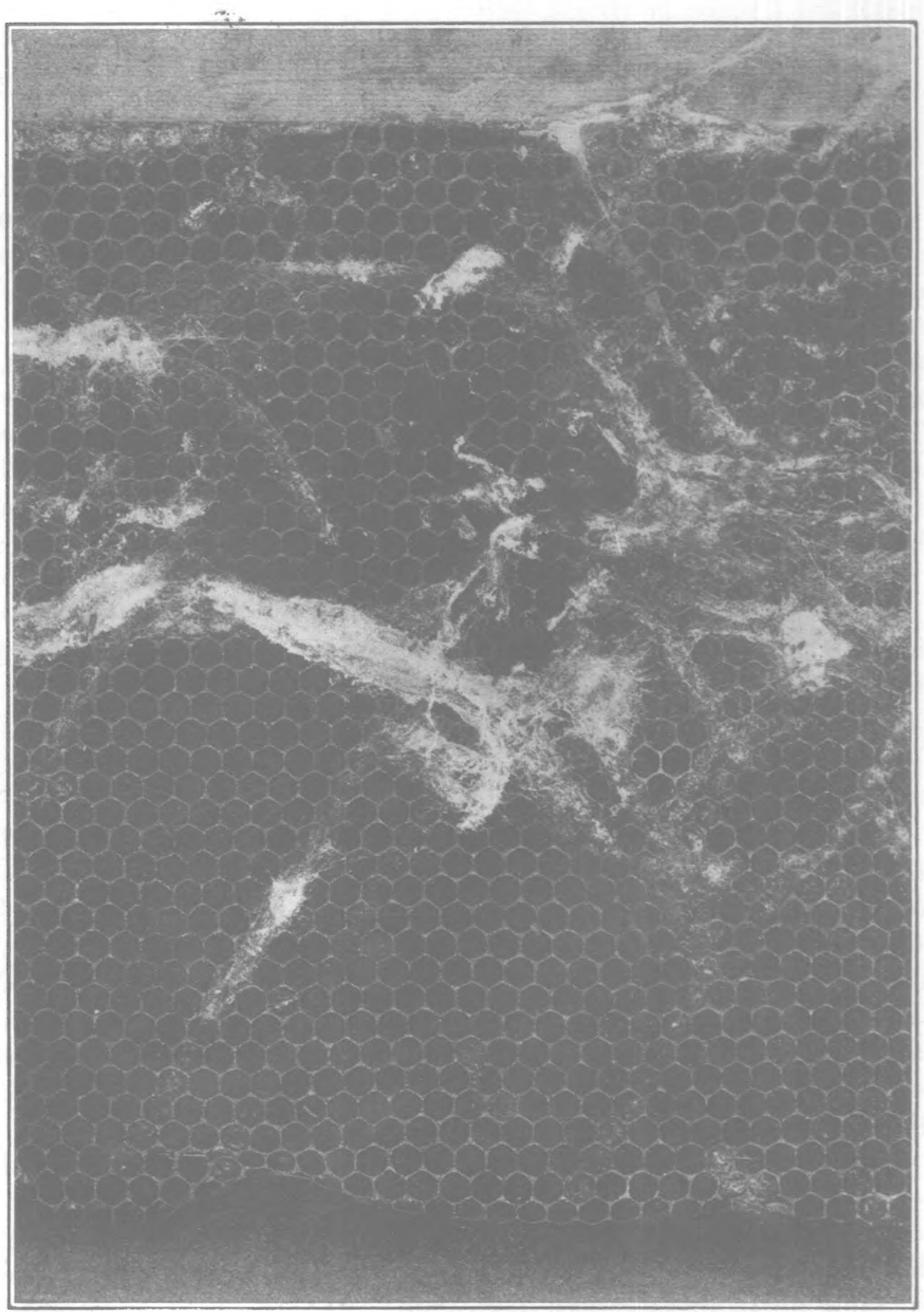

FIG. 1.-Work of the larger wax moth in a brood comb. (Original.)

The wax moths (see fig. 1) are most frequently blamed for the death of colonies, whereas they do no damage to strong, healthy colonies, properly cared for, but enter only when the colony is weakened by queenlessness, lack of 'stores, disease, or some other cause. In the 
majority of the reports of wax-moth depredations received by this department which can be investigated it is found that the trouble is actually an outbreak of a brood disease.

The spraying of fruit trees while in bloom is possibly injurious to bees, and there exists among beekeepers a strong feeling against the practice. Since no entomologist now recommends that fruit trees be sprayed during the blooming period, this is probably rarely done by progressive fruit growers. However, it is frequently reported by beekeepers that they are losing bees by poisoning due to spraying. A number of cases of the death of colonies, reported as caused by poisoning due to spraying while trees were in bloom, have been found to be in reality outbreaks of European foul brood, which is particularly prevalent in the spring and early summer.

Other circumstances to which is often attributed the death of brood or of the colony are chilling, fumes from coke ovens, and malicious poisoning. The wise attitude on the part of the beekeeper is first to suspect diseases as being the cause of any losses which he may sustain, and to be sure that there is no infectious disease present before looking elsewhere for a cause.

\section{NATURE OF THE DISEASES.}

There are two recognized infectious diseases of the brood of bees, now known as American foul brood and European foul brood. Both diseases weaken colonies by reducing the number of emerging bees needed to replace the old adult bees which die from natural or other causes. In neither case are adult bees affected, so far as known. The means used by the beekeeper in deciding which disease is present is the difference in the appearance of the larvæ dead of the two diseases. That the diseases are entirely distinct can not now be doubted, since they show certain differences in the age of the larvæ affected, in their response to treatment, and in the appearance of the dead larvæ. This is made still more certain by a study of the bacteria present in the dead larvæ. Reports are sometimes received that a colony is infected with both diseases at the same time. While this is possible, it is not by any means the rule, and such cases are usually not authentically reported. There is no evidence that chilled or starved brood develops into an infectious disease or that dead brood favors the development of a disease.

\section{NAMES OF THE DISEASES.}

The names American foul brood and European foul brood were applied to these diseases by the Bureau of Entomology, of this department, to clear up the confusion in names which formerly existed. By retaining the words "foul brood" in each name the diseaseinspection laws then in force could be interpreted as applying to 
both diseases. These names $\pi$ ere in no way intended to designate geographical dx tribution. since both dreasen did exist and do now exist in both Europe and America, but $\pi$ ere chosen primarily because they were convenient and edsily remembered names. Their only significance is in indicating where the drseases were first seriously investigated. It was particularly desirable to change the name of the disease now known as European foul brood, since "black brood" entirely fails to be deccriptive and is misleading.

\section{SYMPTOIMS.}

The presence of a particular disease in a colony of bees can be ascertained most reliably by a bacteriological examination, since the si mptoms are somewhat variable. It is possible, however, to describe the usual manifestations of the diseases, and the usual differences, so that the beekeeper can in most cases tell which disease is present.

\section{American Foul Brood.}

American foul brood is frequently called simply "foul brood." It usually shows itself in the larva just about the time that the larva fills the cell and after it has ceased feeding and has begun pupation.

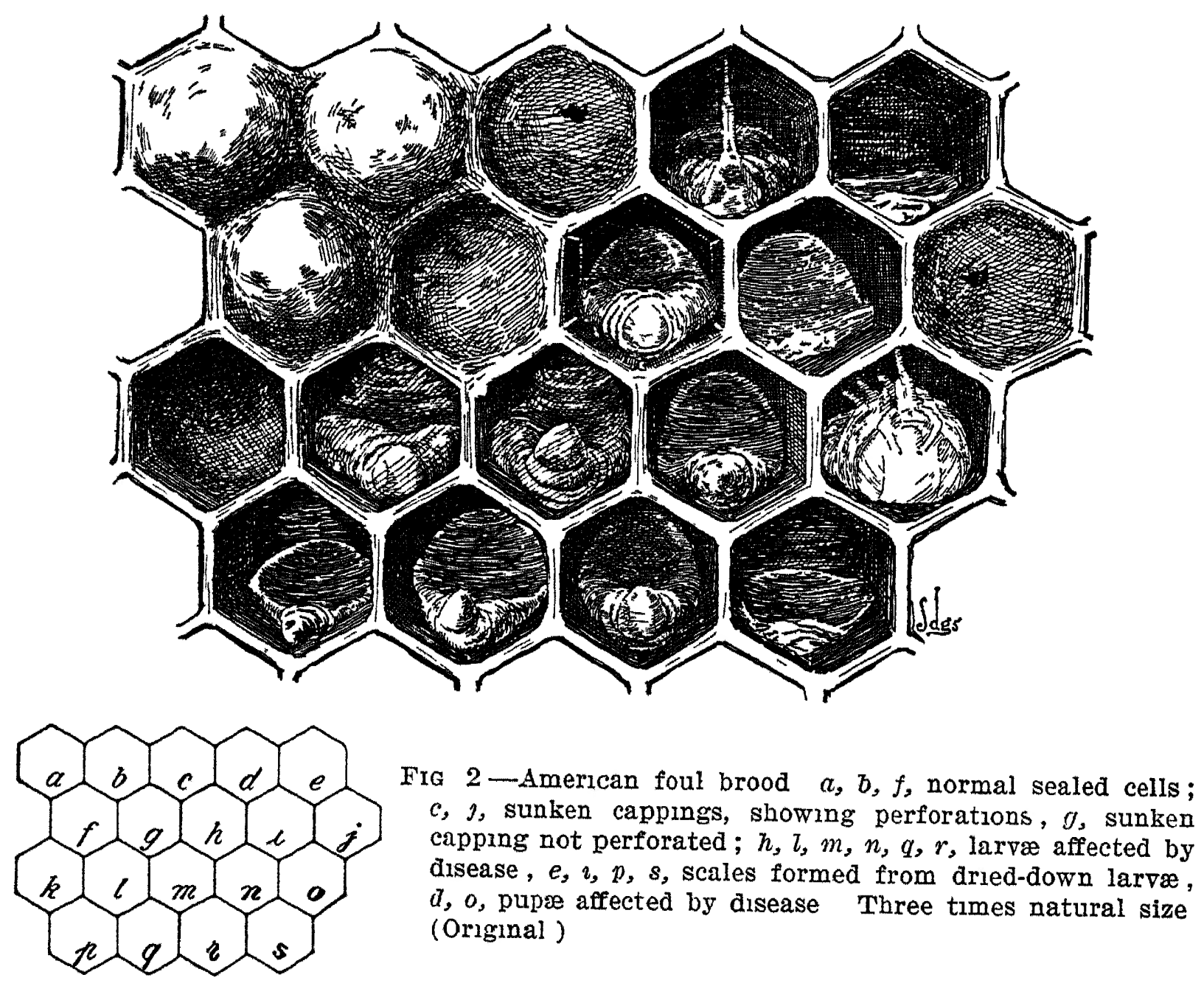

At this time it is sealed over in the comb (fig. 2, $a, b, f$ ). The first indication of the infection is a slight brownish discoloration and the loss of the well-rounded appearance of the normal larva (fig. $2, l)$. At this stage the disease is not usually recognized by the bee- 
keeper. The larva gradually sinks dow $n$ in the cell and becomes darker in color (fig. $2, h, m$ ), and the po-terior end lies against the bottom of the cell. Frequently the segmentation of the larra is clearly marked. By the time it has partially drued down and has became quite dark brown (coffee colored) the most typical characteristic of this disease manifests itself. If a match stick or tooth-plck is inserted into the decaying mass and

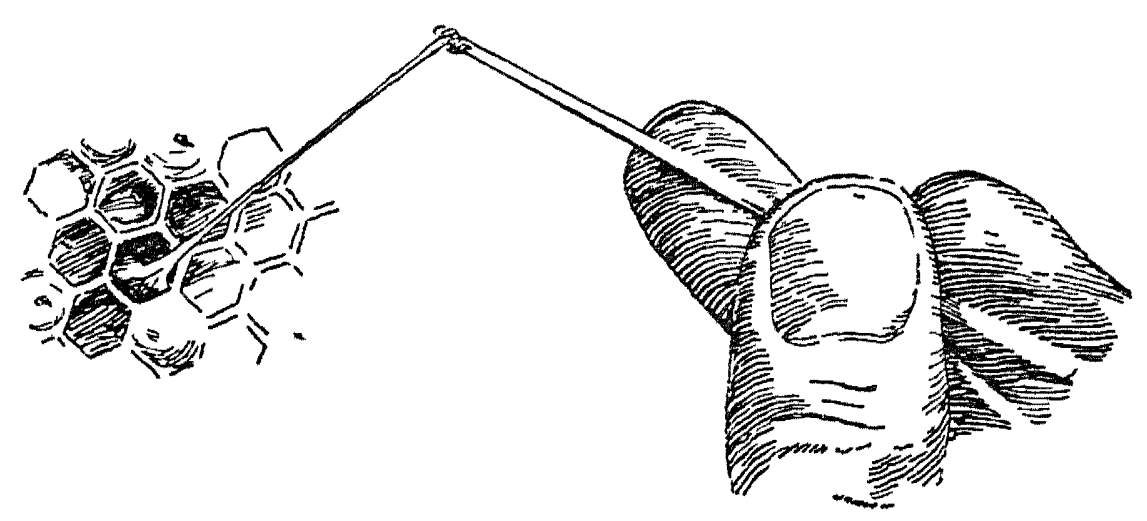

TIG 3-The ropiness of Ameiscan foul brood (Original) withdrawn the larval remains adhere to it and are drawn out in a thread (fig. 3), which sometimes extends for sereral inches before breaking. This ropiness is the chief characteristic used by the beekeeper in diagnosing this disease. The larva continues to diy down and gradually loses its ropiness until it finally becomes merely a

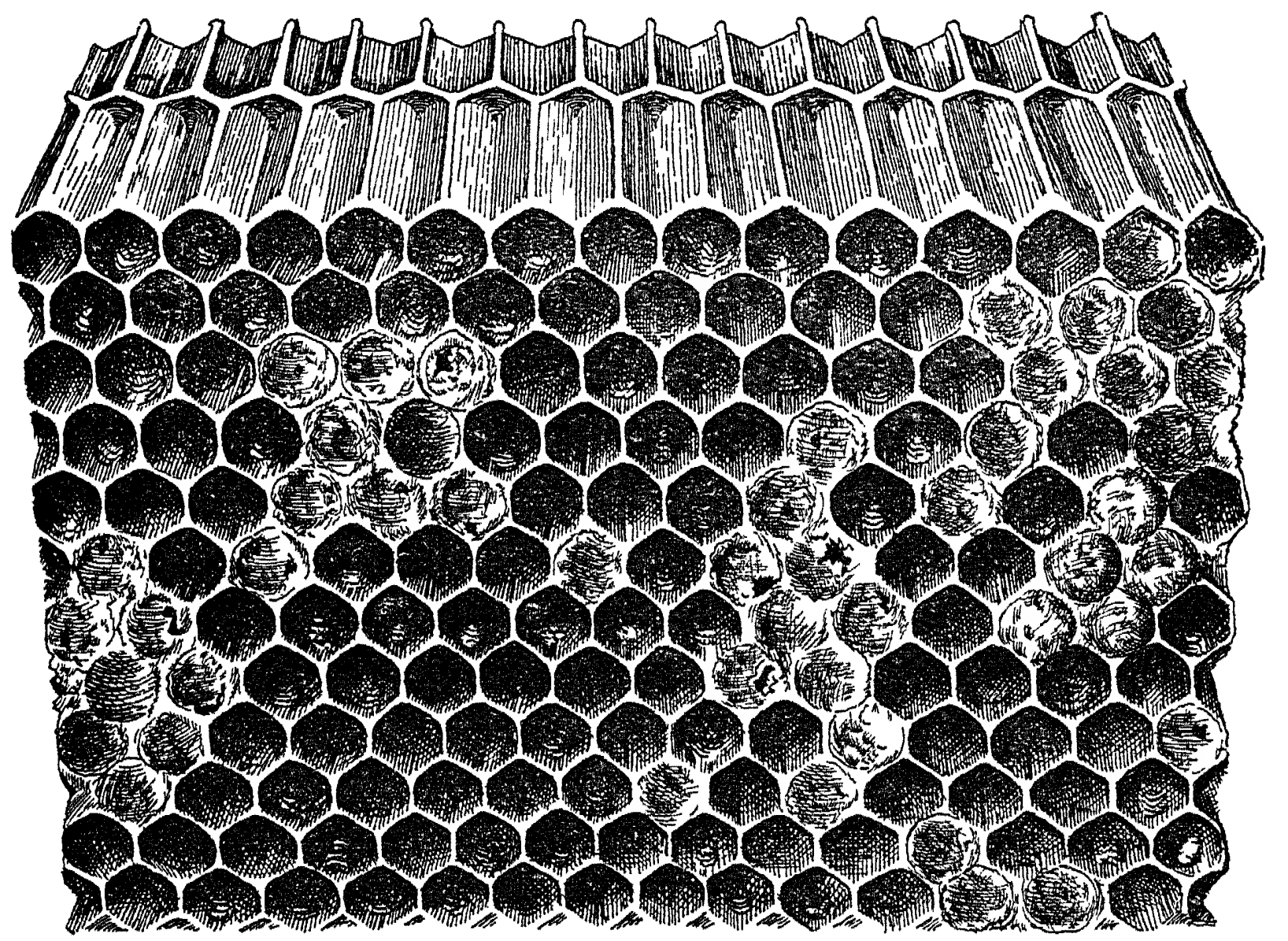

FIG. 4 -American foul biood comb, showing uriegular patches of sunken cappings and scales The position of the comb indicates the best way to view the scales (Original)

scale on the lower side wall and base of the cell (fig. $2, e, p, s$ ). The scale formed by the dried-down larva adheres tightly to the cell and can be removed with difficulty from the cell wall. The scales can best be observed when the comb is held with the top inclined toward the observer so that a bright light strikes the lower side wall (fig. 4). $83568^{\circ}-$ Bull. 442-11-2 
A rery chararteri-tic and usually penetrating odor is often s.oticeable in the decaring larta. Thi, can perhaps bet be likened to the odor of heated gline.

The majority of the larra which die of this disease are attacked after being sealer in the cells. The cappings are often entirely removed by the bees. but when they are left they usually become sunken (fig. 2. g, ., j) and frequently perforated (fig. $, 2, c, j$ ). Is the healthy brood emerges the comb -horrs the scatterer sunken cappings corering dead larre (fig. 4), giving it a character istic appearance.

Pupa also may die of this disease. in which case they, too, dry down

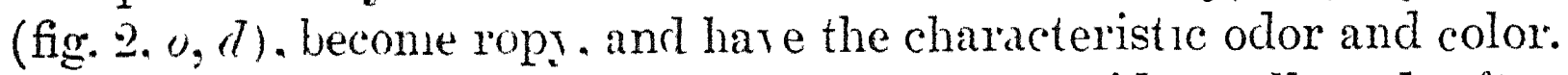
The tongue frequently adheres to the upper side wall and often remains there er en after the pupd has dried down to a scale. Younger unsealed lariæ are sometimes affected. T'sually the direase attacks only worker broorl, but occasional canes are found in which queen and drone brood are diseased. It ss not certain that race of bees, season, or climate have any effect on the rirulence of this disease, except that in walmer climates, where the breeding season is prolonged. the rapidity of derastation is more marked.

European Foul Brood.

European foul brood was formerly called "black brood" or "New York bee disease." The name "black brood" was a poor one, for the color of the dead brood is rarely black or even very dark brown. European foul brood usually attacks the larva at an earlier stage of its development than American foul brood and while it is still curled up at the base of the cell (fig. $5, x^{\prime}$ ). I small percentage of larvæ dies after capping, but sometimes quite young larvæ are attacked (fig. $5, e, m)$. Sunken and perforated cappings are sometimes observed just as in American foul brood (fig. 2, $c, g, j$ ). The earliest indication of the disease is a slight yellow or gray discoloration and uneasy movement of the larva in the cell. The larva loses its well-rounded, opaque appearance and becomes slightly translucent, so that the tracheæ may become prominent (fig. $5, Z$ ), giving the larvæ a clearly segmented appearance. The larva is usually flattened against the base of the cell, but may turn so that the ends of the larva are to the rear of the cell (fig. $5, p$ ), or may fall away from the base (fig. 5 , $e, g, l)$. Later the color changes to a decided yellow or gray and the translucency is lost (fig. $5, q, h$ ). The yellow color may be taken as the chief characteristic of this disease. The dead larva appears as a moist, somewhat collapsed mass, giving the appearance of being melted. When the remains have become almost dry (fig. $5, c$ ) the tracher sometimes become conspicuous again, this time by retaining their shape, while the rest of the body content dries around them. Finally all that is left of the larva is a grayish-brown scale against 


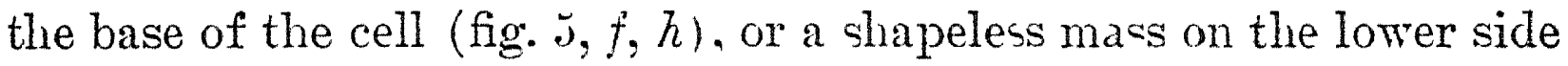
wall if the larra did not retain its normal position (fig. $5, n, 0$ ). Tery few scales are black. The ccales are not adhesire, but are easily remored, and the bees carry out a great many in their efforts to clean house.

Decaying larræ which have died of this diseace are usually not ropy as in American foul brood, but a slight ropiness is sometimes observed. There is ucually little odor in European foul brood, but sometimes a sour odor is present, which reminds one of reast fermentation. This diceace attacks drone and queen larr ${ }^{1}$ almost as quickly as those of the workers.
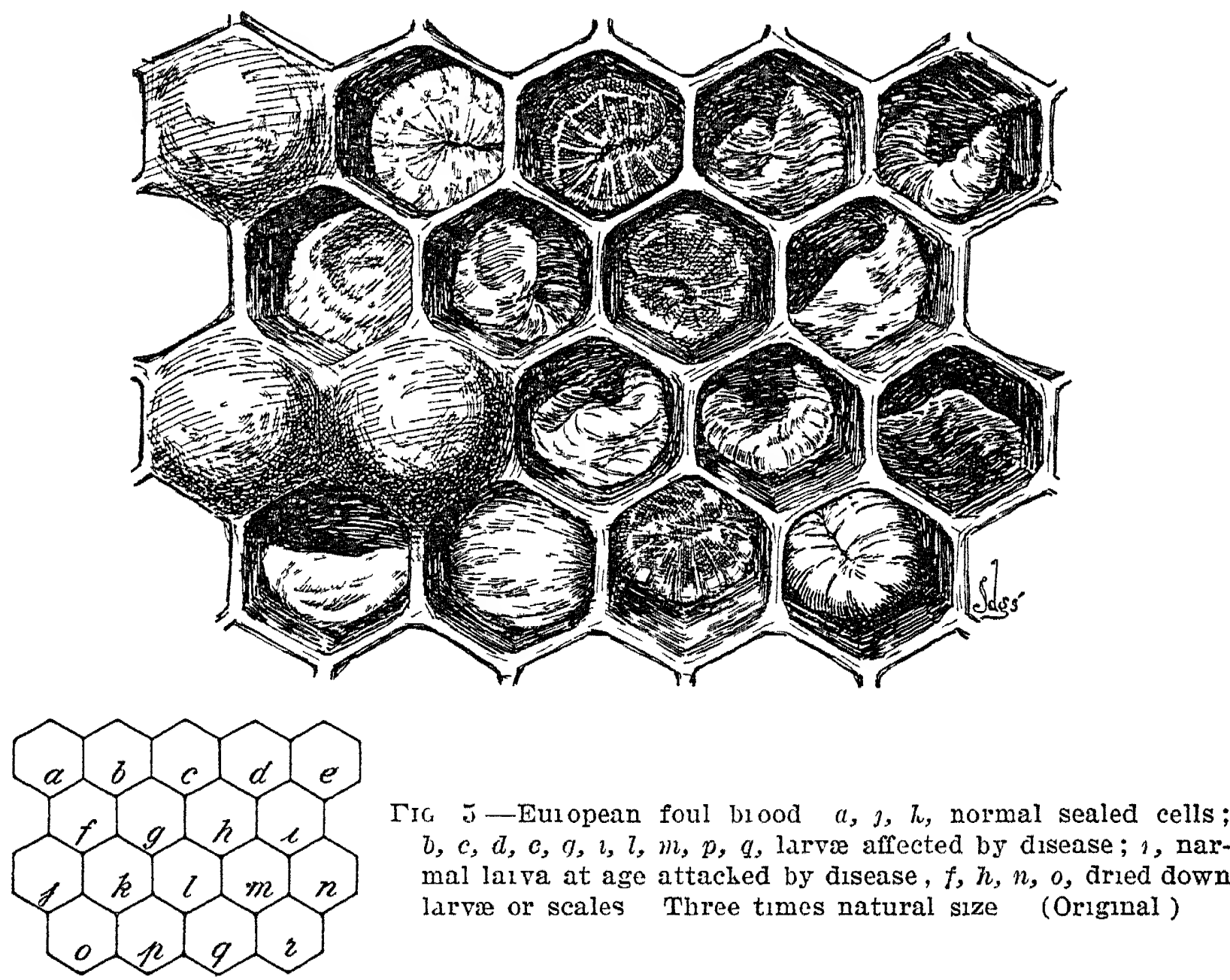

European foul brood is more destructive during the spring and early summer than at other times, often entirely disappearing during late summer and autumn, or during a heavy honey flow. Italian bees seem to be better able to resist the ravages of this disease than any other race. The disease at times spreads with startling rapidity and is most destructive. There it is prevalent a considerably larger percentage of colonies is affected than is usual for American foul brood. This disease is very variable in its symptoms and other manifestations and is often a puzzle to the beekeeper.

\footnotetext{
1. The tendency of this disease to attach queen larve is a scrious drawback in traat ment Frequently the bees of a diseased colony attempt to supersede their queen, but the larvo in the queen cells often dre, leaving the colony hopelessly queenless. The colony is thus depleted very rapidly

442
} 
In addition to the two infecuon-di-eases just described, brood dead from other cam-en 1 , often ob-eried. The mot common disease of thi- kind is what 1 known among beekeepers as "pickle brood." Thi name is -eemingly appleed to a great many different appearances and nothing is known of the cause or methods of spread. The most trpical form kills the larra when it has extended itself in the cell. The larra usually lies on its back with the head turned upward. The color varie, but is frequently light yellow or brown, and the head is often almo-t black. The body is swollen and the contents watery. and the hear may be quite hard. There is no ropiness. In case the larra are sealed before dying the cappings are ucually normal. The name usually applied to this condition was unwisely cho-en. and for the present and until more is known concerning the dicea-e it in -poken of as the "so-called pickle brood."

This trouble doe not appear to be infectious and is usually not serious, except that in the aggregate it may cause loss by weakening colonies. To treatment is necessary, as the trouble usually soon disappearc. The most -erious aspect of this disease is that it is often mirtaken for one of the infectious diseases, and the colony is needlessly treated.

Brood dead of other causes.

Many different external factor, may cause brood to die. If brood is killed by chilling in the -pring or fall, or by overheating in extremely hot weather, or in shipping colonies of bees, or by starvation. the loss is often mistakenly attributed to an infectious disease. Such dead brood is soon removed by the bees. When the cause is removed the trouble then scon disappears. When a considerable quantity of brood is killed a disagreeable odor is usually present.

"Bald-headed brnod."

It sometimes happens that unsealed or only partially sealed pupæ, known as "bald-headed brood," are observed in the hive, and frequently beginners mistake such a condition for disease. The partially built capping is often mistaken for the punctured capping of American foul brood. If, on examination, the pupæ are normal no fear need be entertained.

MIETHODS OF SPREAD.

Both American foul brood and European foul brood spread from colony to colony and from apiary to apiary in much the same way. The common means of carrying the virus is in honey which has become contaminated. The disease may be carried when bees rob a hive in which a colony has died of disease or may be transmitted by 
the use of honey from diseaced colonies for feeding bees. It is not always necendry that bees be intentionally fed for them to get disease from contaminated honey. Di-carded honey receptacle- which have contained honey from a contaminated colonr. if not thoroughly cleaned, may contain enough honey to carry di-ease to a healthy apiary. This may occur in the ricinity of bakerie- or confectionery shope, or may eren occur when empty honey bottles are thrown out from private housec. It is al-o possible to introduce disease into a colony in introducing queen bees purchaced from a distance, probably due to the use of contaminated honey in makng the candy to supply the queen cages.

Precautionary Measures.

In combating diseases it is much better to prevent disease from getting a foothold than it is to eradicate it after it has begun its work. All beekeepers, wherever located, should practice the following precantionary measuren:

(1) If a colony becomes weak from any cause, or if disease is suspected, contract the entrance to prevent robbing, and if robbing is imminent cloce the entrance entirely.

(2) Never feed honey purchased on the open market. In case of doubt as to the source of honey feed sugar sirup.

(3) If within the range of possibility, see that no honey that comes from diseased apiaries is sold in the neighborhood. This may sometimes be accomplished by cultivating the home market so that there will be no incentive for bringing in other honey.

(4) In introducing purchased queens, transfer them to clean cages provided with candy known to be free from contamination, and destroy the old cage, candy, and accompanying workers. Of course, if it is certain that the queen comes from a healthy apiary this is not necessary.

(5) Colonies of bees should never be purchased unless it is certain that they are free from disease.

(6) The purchase of old combs or second-hand supplies is dangerous, unless it is certain that they came from healthy apiaries.

\section{TREATIMENT FOR BOTH INFECTIOUS DISEASES.}

The treatment of an infectious bee disease consists primarily in the elimination or removal of the cause of the disease. It is definitely known that American foul brood is caused by a bacillus named Bacillus larve. In treating this disease, therefore, the aim of the manipulation is to remove or destroy all of the bacteria of this species. It should be remembered that the effort is not to save the larve that are already dead or dying, but to stop the further de- 
rastation of the diceare by remoring all material capable of transmitting the cause of the tromble.

The cause of European foul brond i- not definitely known, but the same principles of treatment doubtle-s apply in this disease also. In all of the operation great pains hould be taken not to spread the disease through carelessness. After handling a diseased colony the hands of the operator chould be washed with water to remove any honey that may be on them. It does not pay to treat colonies that are considerabiy weakeneil by dicease. In case there are cereral such colonies ther should be united to form strong, vigorous colonies before or during treatment.

In discussing treatment it is assumed that hives with movable frames are in use. Box hives are a menace in regions where disease is present. The-e may be treated for cliseace by drumming the colony into another box and then hiving it like a swarm in a hive, but box hives are not profitable and are ecpecially to be condenned where disease is present on account of the difficulty in inspecting and treating.

\section{Shaking Treatment.}

The shaking treatment consists essentially in the removal of all infected material from the colony, and in compelling the colony to take a fresh start by building new combs and gathering fresh stores. This is done by shaking the bees from the old combs into a clean hive on clean frames.

Time of treatment.-The shaking treatment should be given during a flow of honey, so that other bees in the apiary will not be inclined to rob. If this is not possible the operation may be performed under a tent made of mosquito netting. The best time is during the middle of a clear day when a large number of bees are in the field. It is sometimes recommended that shaking be done in the evening, but this is impossible if many colonies are to be treated. The colony can be handled more quickly when the field force is out of the hive.

Preparation.-All implements that will be needed, such as queen and drone trap, hive tool, and lighted smoker, should be in readiness before the operation is begun. A complete clean hive with frames is provided, as well as a tightly closed hive body in which to put the contaminated combs after shaking. An extra hive cover or some similar apparatus should be provided to serve as a runway for the bees as they enter the new hive. The new frames should contain strips of comb foundation from one-fourth to 1 inch wide. Full sheets are not desirable, and if combs built on full sheets of foundation are desired they may be built later.

Operation.-The old hive containing the diseased colony (fig. $6, A$ ) is now lifted to one side out of the flight of returning field bees and the clean hive $(B)$ set exactly in its place. The cover $(G)$ is 442 
now taken off and a fen frames $(E)$ removel from the center of the hive. If unspaced frames are ued. tho-e remaining in the hive should be pushed tightly to either cide of the hive, thus making a barrier beyond which the bees can not crawl an ther more to the top of the hive after chaking. This largely prevent them from getting on the outside of the hive. If self- - pacing frames are used, a couple of thin boards laid on the top bars on either -ide will accomplish the same result. The runway $(D)$ is put in place in front of the entrance. The old hive is now opened for the fir-t time. The frames are removed one at a time. lowered part way into the new hive, and with a quick downward shake the bees are dislodged. The frames are then put into the extra hive body $\left(C^{\prime}\right)$ and immediately covered to prevent robbing. Ifter all the frames are shaken the bees remaining on the sides of the old hive (1) are shaken out.

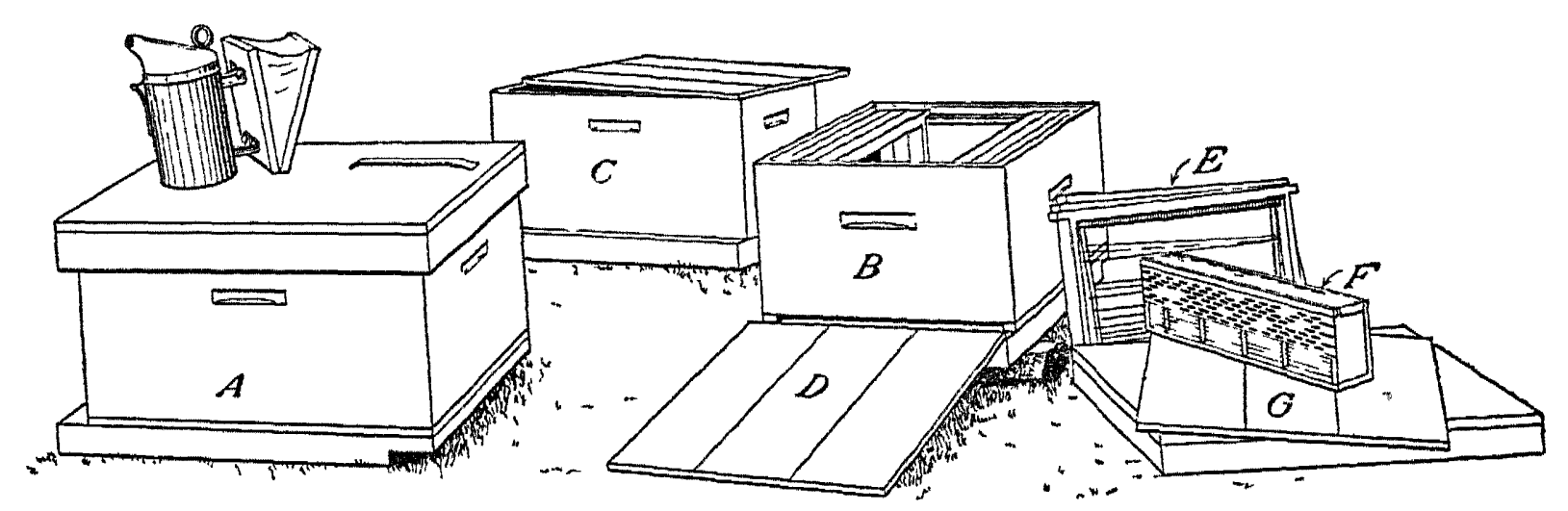

Fig 6-Apparatus for the shabing treatment $A$, IIve containing diseased colony (formerly in position of $B$ ) ; $B$, clean hive, $C$, empty hive to recelve combs after shaking; $D$, hive covel used as Iunway, $E$, frames lemored flom $B$ to give $100 m$ for shaking; $F$, queen and drone trap, $G$, covel tor clean hive, $B$ (Original)

If honey is coming in freely, so that thin honey is shaken out of the combs, cover the runway $(D)$ with newspapers and shake the bees in front of the new hive $(B)$, leaving all frames in place and the cover on. After the operation the soiled newspapers should be destroyed. In shaking in front of the entrance the first one or two frames should be so shaken that the bees are thrown again t the entrance, where they can locate the hive quickly. They the fan their wings and the others follow them into the hive. If this is not done the bees may wander about and get under the hive or in some other undesirable place.

After the bees are mostly in the new hive a queen and drone trap $(F)$ or a strip of perforated zinc is placed over the entrance to prevent the colony from deserting the hive. The queen can not pass through the openings in the perforated zinc and the workers will not leave without her. By the time that new combs are built and new brood is ready to be fed, any contaminated honey carried by the bees into their new hive will have been consumed and the 
disease will rurely reappear. If it thould. a repetition of the treatment will be neces:ary.

Saving the healthy brood.-The old combs are now quickly removed. If sereral colonie- are being treated at one time it may pay to stack sereral hive bodie- containing contaminated combs over a weak diseased colony to allow most of the healthy brood to emerge, thereby strengthening the reak colony. After 10 or 12 days this colony is treated in turn and all the combs rendered into wax. If only one or two colonies in a large apiary are being treated it will not pay to do this.

Saving the wax.-Any but a rery small apiary should have included in its equipment a wax press for removing wax from old combs. After the contaminated frames are taken to the honey house

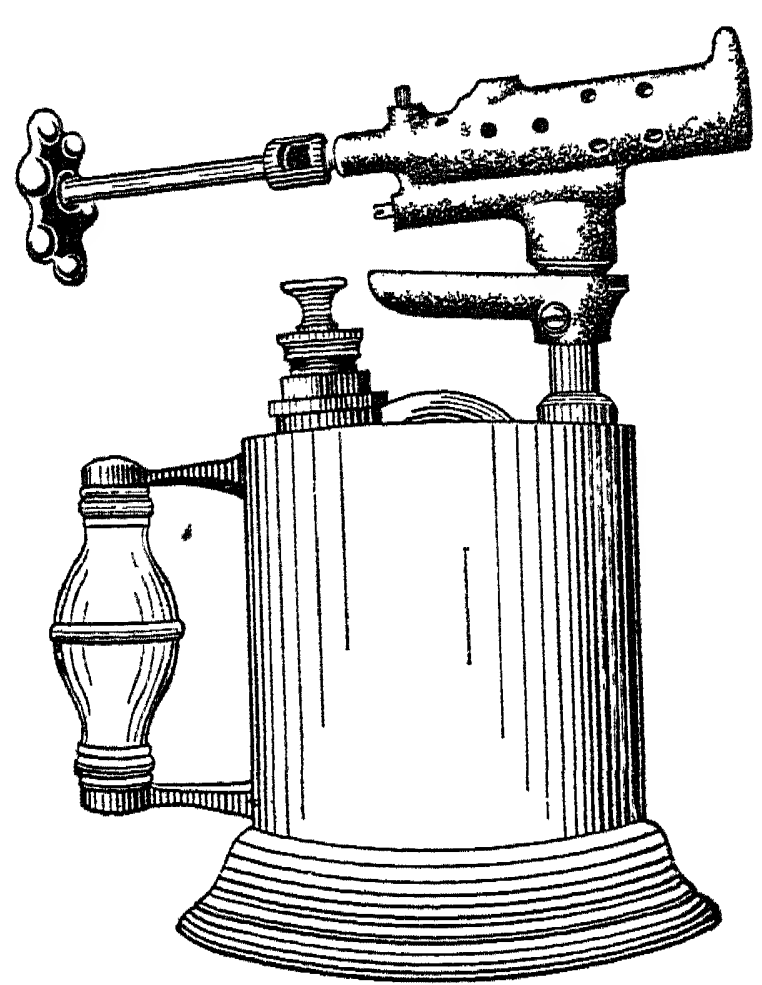

FIG. 7.-Gasoline torch (Original) the combs should be kept carefully corered, so that no bees can reach them until the wax can be rendered. This should not be delayed very long or the combs may be ruined by wax moths. The slumgum or refuse remaining after the wax is removed should be burned. Contaminated combs should not be put into a solar wax extractor for fear of spreading the disease. The wax from contaminated combs may safely be used for the manufacture of comb foundation.

Cleaning the hive.-The hive which has contained the diseased colony should be thoroughly cleaned of all wax and honey, and it is desirable that it be carefully disinfected by burning out the inside with a gasoline blueHame torch (fig. 7 ). If this piece of apparatus is not available several hive bodies may be piled together on a hive bottom and some gasoline or kerosene poured on the sides and on some straw or excelsior at the bottom. This is then ignited and after burning for a few seconds a close-fitting hive cover "is placed on top of the pile to extinguish the flames. The inside of the hive bodies should be charred to a light brown. The careful cleaning and disinfection of frames always costs considerably more in labor than new frames would cost, but these also may be carefully cleaned and used again. Frames may be cleaned by boiling in water for about half an hour, but this frequently causes them to warp badly. The disinfection of hives and frames with chemicals is not recommended, as the ordinary strengths used are valueless for the purpose. 
Disposal of the honey.-If there is a considerable quantity of honey in the contaminated combs it may be extracted. This honey is not safe to feed to bees without boiling. but it is absolutely safe for human consumption. If there is a comparatively small quantity it may be consumed in the beekeeper's family, care being taken that none of it is placed so that the bees can ever get it.

To put such honey on the market is contrary to law in some States. There is always danger that an emptied receptacle will be thrown out where bees can have access to it, thus causing a new outbreak of disease. It can be safely used for feeding to bees, provided it is diluted with at least an equal volume of water to prevent burning, and boiled in a closed vessel for not less than one-half hour, counting from the time that the diluted honey first boils vigorously. The honey will not be sterilized if it is heated in a vessel set inside of another containing boiling water. Boiled honey can not be sold as honey. It is good only as a food for bees, and even then should never be used for winter stores, as it will probably cause dysentery.

The second shake.-Some beekeepers prefer to shake the bees first onto frames containing strips of foundation as above described, and in four days to shake the colony a second time onto full sheets of foundation, destroying all comb built after the first treatment. This insures better combs than the use of strips of foundation, but is a severe drain on the strength of the colony. Since it is desirable to have combs built on full sheets, the best policy is to replace any irregular combs with full sheets of foundation or good combs later in the season.

The cost of shaking.-If the treatment just described is given at the beginning of a good honey flow, it is practically equivalent to artificial swarming and results in an actual increase in the surplus honey, especially in the case of comb-honey production. The wax rendered from the combs will sell for enough to pay for the foundation used if full sheets of foundation are employed. Since a colony so treated actually appears to work with greater vigor than a colony not so manipulated, the cost of treatment is small. If treatment must be given at some other time, so that the colony must be fed, the cost is materially increased. In feeding, it is best to use sugar sirup, or honey that is known to have come from healthy colonies.

Treatment with Bee Escape.

As a substitute for the shaking treatment just described, the bees may be removed from their old combs by means of a bee escape. The old hive is moved to one side and in its place is set a clean hive with clean frames and foundation. The queen is at once transferred to the new hive and the field bees fly there on their return from the 
field. The infected hive is now placed on top of or close beside the clean hive and a bee excape placed over the entrance, so that the younger bees and those which later emerge from the cells may leave the contaminated hive but can not return. They therefore join the colony in the new hive. If desired, the infected hive may be placed above the clean hive and a tin tube about 1 inch in diameter placed from the old entrance so that the lower end is just above the open entrance of the new hive. The bees follow down this tube and on their return enter the new hive. When all of the healthy brood has emerged from the infected combs the old hive is removed. This treatment induces less excitement in the apiary and is preferred by many experienced beekeepers. Care should be taken that the old hive is absolutely tight to prevent robbing. The old hive and its contents of honey and wax are treated as indicated under the shaking treatment.

\section{Fall Treatment.}

If it is necessary to treat a colony so late in the fall that it would be impossible for the bees to prepare for winter, the treatment may be modified by shaking the bees onto combs entirely full of honey so that there is no place for any brood to be reared. This will usually be satisfactory only after brood rearing has entirely ceased. Unless a colony is quite strong it does not pay to treat in the fall, but it should be destroyed or united to another colony. In case a diseased colony dies outdoors in the winter there is danger that other bees may have opportunity to rob the hive before the beekeepers can close the entrance. In case bees are wintered in the cellar it is more advisable to risk wintering before treatment, for if the colony does die the hive will not be robbed.

\section{Drugs.}

Many European writers have in the past advocated the use of various drugs for feeding, in sugar sirup, to diseased colonies, or the fumigation of contaminated combs. In the case of American foul brood, of which the cause is known, it has been found that the drugs recommended are not of the slightest value and no time should be wasted in their use.

\section{TREATMENT FOR EUROPEAN FOUL BROOD.}

European foul brood is a very peculiar disease and its cause has not yet been satisfactorily determined. It is, therefore, impossible to discuss the treatment of this disease as definitely as that of American foul brood. From the experience of many careful beekeepers it is, however, possible to suggest some additional manipulations which may be tried by experienced beekeepers. The treatments given previously are strongly recommended for this disease. 
Introduction of Italian Stock.

Since, as stated previously (p. 11), Italian bees seem to be better able to withstand European foul brood than are other races, it is recommended that apiaries in regions where this disease is prevalent be requeened with young, rigorous Italian queens of good stock. This should be done whether or not the shaking treatment is given.

Dequeening.

It has been found that the removal of the queen and the keeping of the colony queenless for a period often results in the disappearance of European foul brood. The length of time that this should be done is in dispute. Mr. E. W. Alexander, who advocated this method, ${ }^{1}$ recommended that the colony be kept queenless (by cutting out all queen cells at the end of 9 days) for a period of 20 days, at which time a cell containing a queen of Italian stock ready to emerge is to be given the colony. The young queen will thus begin to lay in about 27 days after the old queen has been remored, or in at least 3 days after the last of the drone brood has emerged. Other writers have advocated a shorter time.

The dequeening treatment is not always successful, and it is therefore recommended that care be exercised in trying it. Since there is a considerable percentage of successful results, this would inclicate that there is an important principle involved. It should not be forgotten, however, that European foul brood often disappears in the late summer of its own accord if the case is not serere (p. 11), and it is probable that in many of the cases of dequeening reported as successful the disease would have disappeared without the treatment. This treatment is suggested only for the experienced beekeeper.

INSPECTION OF APIARIES.

Several States have passed laws providing for the inspection of apiaries for contagious disease and creating the office of apiary inspector. The men holding these offices are usually practical beekeepers, capable of giving excellent advice regarding disease, and it is desirable, when disease exists in a community, that the owners of apiaries take steps to learn who the inspector is and to notify him of the existence of disease. The Bureau of Entomology of this department can usually give information concerning the inspector and is always glad to be of service in bringing the beekeepers and inspectors in touch with one another.

Apiary inspection has proved beneficial to the beekeeping industry in spreading information concerning the nature, symptoms, and

1 Alexander, E W.-How to rid your apiary of black brood. Gleanings in Bee Culture, vol. 33 , pp 1125-1127, 1905 .

442 
treatment of the contagioun disea-es and particularly in compelling negligent and careles- beekeepers to treat their diseased colonies. It is quite po-ible for the individual beekeeper to clean up his own apiare by following the directions giren in this bulletin, but unless all of the beekeepers in the neighborhood do the came thing there will probably be a recurrence of the trouble due to infection from outside apiariec. It is therefore manifestly to the advantage of the beekeepers that they cooperate with the inspectors in the fight against diseases.

\section{EXAMINATION OF SAMPLES OF DISEASED BROOD.}

The Bureau of Entomology of this department is prepared to assist in the diagnosis of disease in cases where the beekeeper is unable to tell whether or not disease is present, or to determine which disease $i$ in his apiary. Samples of brood comb about 5 inches square containing diseased or dead larvæ should be -ent by mail in a strong wooden or tin box. The comb should not be wrapped in paper or cotton, but should be cut to fit the box closely. It is not possible to diagnose from empty combs, and no honey should be included in the sample, as it is valueless in diagnosis and will probably spoil the sample as well as other mall matter. The name of the sender must always appear on the package, and any available data should be sent in a separate letter. Never inclose a letter in the box with the sample.

\section{THE DISEASES OF ADULT BEES.}

The diseases affecting adult bees are but imperfectly known. At present four are known to beekeepers by name. Whether these are entirely distinct or whether under each name one or more diseases are included is not known. As stated in the introduction, these diseases have not been sufficiently investigated to give much help to the practical beekeeper.

\section{DYSENTERY.}

Dysentery affects bees only in the winter and is manifested by a distension of the abdomen, due to an accumulation of fecal matter in the intestine. When a day warm enough for flight occurs the bees fly from the hive to cleanse themselves, and the hive and surroundings are spotted with yellow excreta. After a good cleansing flight the trouble usually disappears, but if the bees are unable to fly they often die in great numbers. It is generally believed that dysentery is due to improper winter stores, the honey containing too high a percentage of indigestible matter. Honeydew honey almost always produces dysentery, while bees wintered on high-class honey or sugar sirup are not affected. From the wide experience of many bee- 
keepers in this matter it is safe to assume that this explanation of the disease is the correct one, and consequently great care should be exercised that the colonies are provided with good stores for winter.

Recently it has been claimed that there are two trpec of dysentery, one form as above described and another form which is infectious. American beekeepers are not familiar with an infectious dysentery, and in practical manipulations it is necessary to consider only the type above described.

THE SO-CALIED PARALYSIS.

It is quite possible that under the name "paralysis" are included several distinct diseases. This is indicated by the variety of symptoms reported by beekeepers and the number of different seasons and conditions under which the disease is supposed to occur. The usual manifestation described is that the worker bees are seen crawling in front of the hive with their abdomens trembling. The abdomens are also frequently distended. The bees often climb grass blades and on attempting to fly from the top fall again to the ground. Frequently the bees so affected are almost hairless. The same trembling motion may often be observed on opening the hive. The colony is often depleted very rapidly. There is no evidence that the disease is infectious.

The cause of this peculiar trouble is unknown, and no remedy can be recommended. It is claimed by some writers that a salt-water spray applied to the combs or salt or sulphur sprinkled on the top bars or entrance is sometimes an effective remedy.

ISIE OF WIGHT DISEASE.

Recently a supposedly infectious disease of adult bees has decimated the bees on the Isle of Wight and is said to be spreading in England. It resembles somewhat the so-called paralysis. No treatment other than destruction to prevent the spread of the disease has been recommended. So far as is known no trouble of this kind has been experienced in America.

\section{SPRING DWINDLING.}

It sometimes happens that the adult bees in a colony die off in the spring more rapidly than they are replaced by emerging brood. This dwindling may be diminished somewhat by keeping the colony warm and by stimulative feeding, so that all of the energy of the old bees may be used to the best advantage. This condition is probably due to the fact that the colony goes into winter with too large a percentage of old worn-out bees. To prevent this, brood rearing should be continued as late as possible in the fall; if necessary, by stimulative feeding. 


\section{PUBLICATIONS OF THE DEPARTMENT OF AGRICULTURE ON BEE DISEASES.}

There are several other publications of the Bureau of Entomology of this department which deal with bee diseases. They may be obtained on request to the Editor and Chief of the Division of Publications, Department of Agriculture, and are the following:

Circular No. 94, "The Cause of American Foul Brood." By G. F. White, Ph. D. 1907. $4 \mathrm{pp}$

This publication contains a brief account of the investigations which demonstrated for the first time the cause of one of the brood diseases of bees, American foul brood.

Bulletin No. 70, "Report of the Meeting of Inspectors of Apiaries, San Antonio, Tex., November 12, 1906." 1907. 79 pp., 1 pl.

Contains an account of the history of bee-disease investigations, the relationship of bacteria to bee diseases, and a discussion of treatment by various inspectors of apiaries and other practical beekeepers who are familiar with diseases of bees.

Bulletin No. 75, Part II, "Wax Moths and American Foul Brood." By E. F. Phillips, PL. D. 1907. Pp. 19-22, 3 pls.

An account of the behavior of the two species of wax moths on combs containing American foul brood, showing that moths do not clean up the disease-carrying scales.

Bulletin No. 75, Part III, "Bee Diseases in Massachusetts." By Burton N. Gates. 1908. Pp. 23-32, map.

An account of the distribution of the brood diseases of bees in the State, with brief directions for controlling them.

Bulletin No. 75, Part IV, "The Relation of the Etiology (Cause) of Bee Diseases to the rreatment." By G. F. White, Ph. D. 1908. Pp. 33-42.

The necessity for a knowledge of the causes of bee diseases before rational treatment is possible is pointed out. The present state of knowledge of the causes of disease is summarized.

Technical Series, No. 14, "The Bacteria of the Apiary, with Special Reference to Bee Diseases." By G. F. White, Ph. D. 1906.50 pp.

A study of the bacteria present in both the healthy and the diseased colong, with special reference to the diseases of bees.

442 


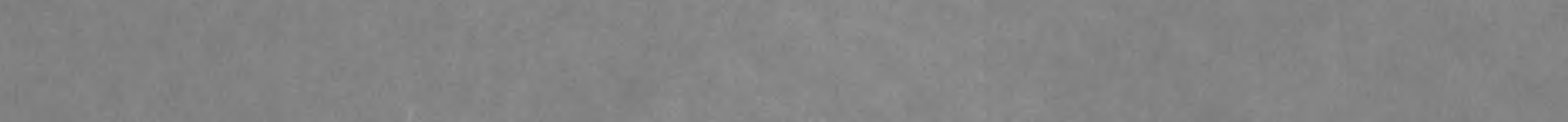

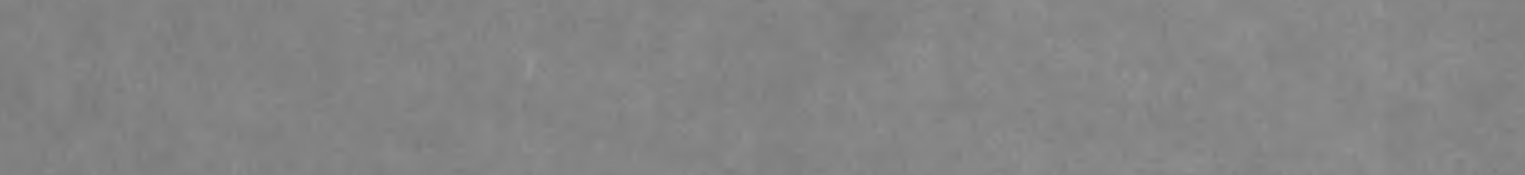

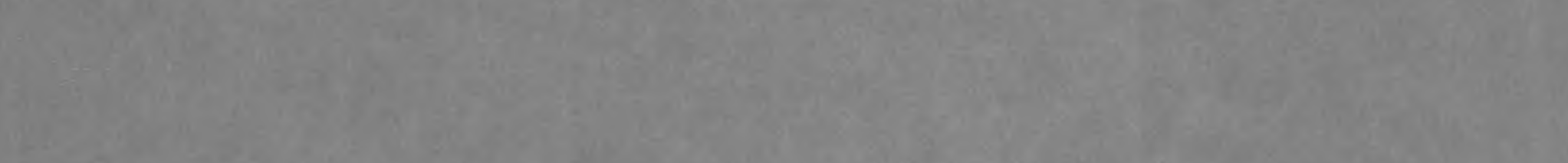
Pe.

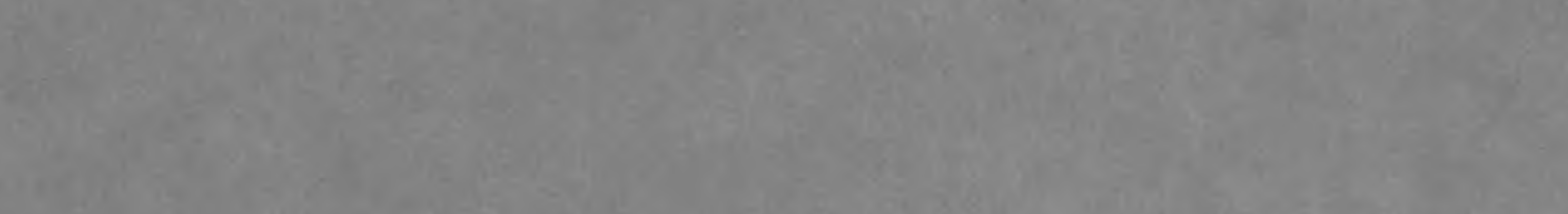

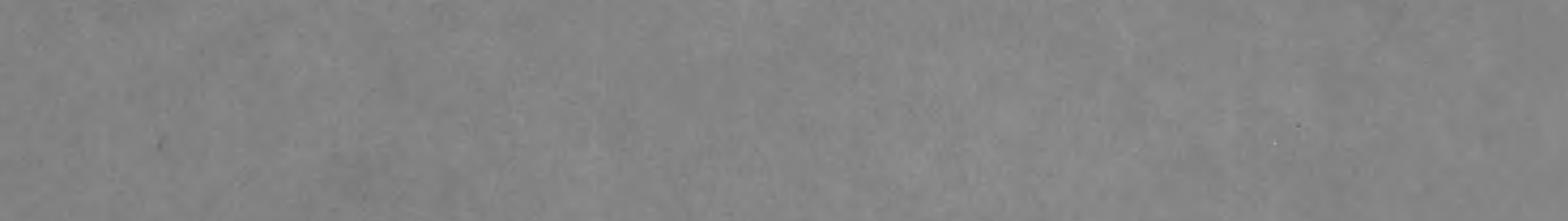

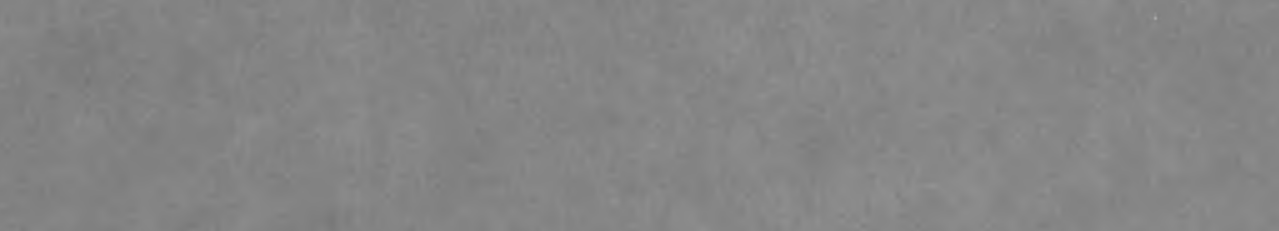

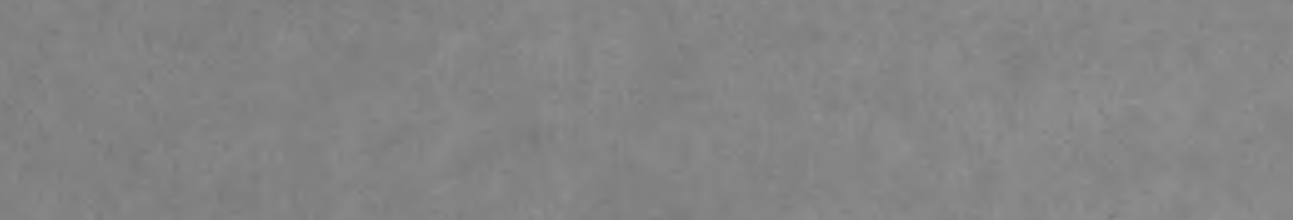

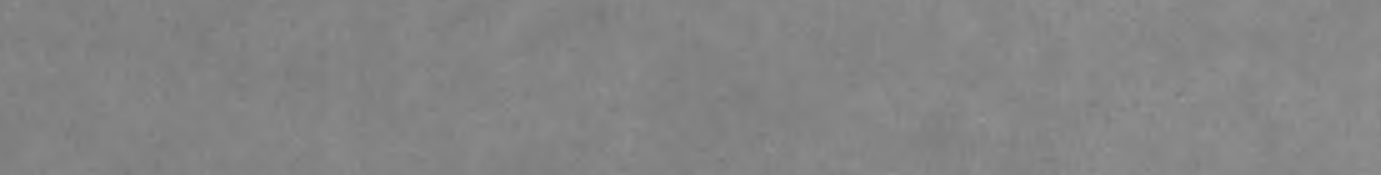

(3)

W.

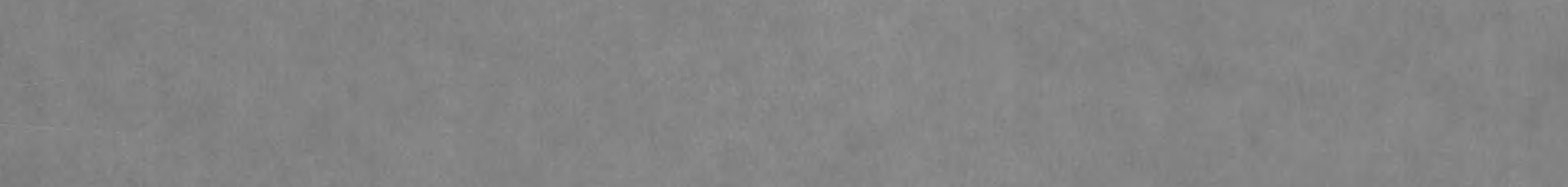

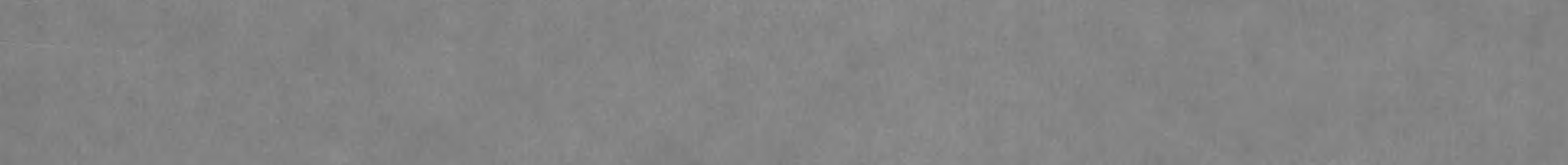

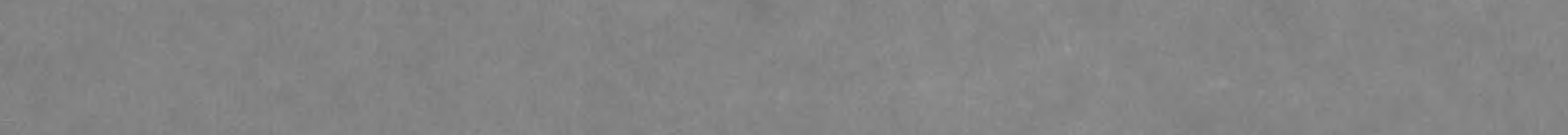

-

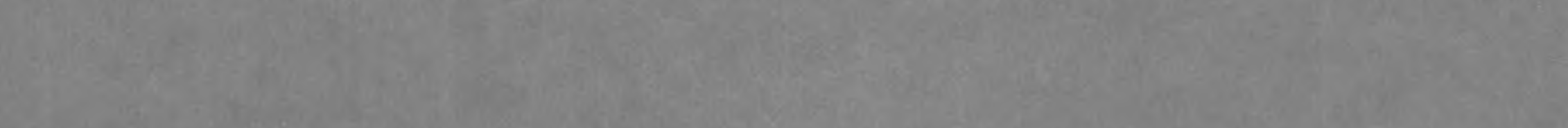

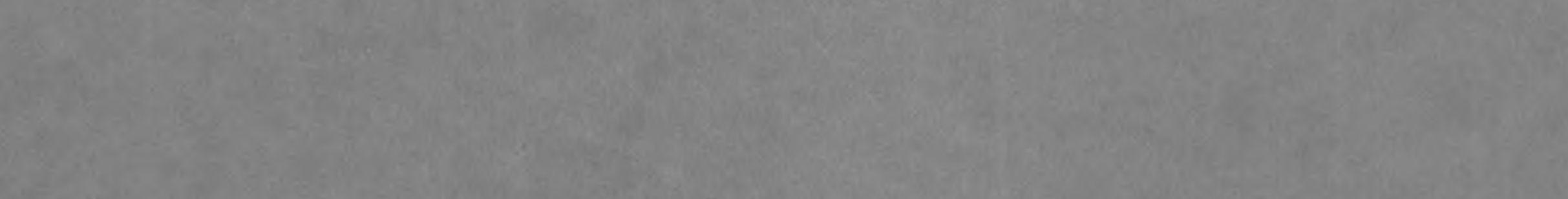

